\title{
PERWUJUDAN INDONESIA LAYAK ANAK (Studi Kasus PKBM Kasih Bundo Kota Bukittinggi Sebagai Penyelenggara Pendidikan Kesetaraan)
}

\author{
Eka Pasca Surya Bayu", Dewi Sari Wahyuni \\ (Mahasiswa S3 Ilmu Pendidikan Universitas Negeri Padang) \\ e-mail: ekapascha.suryabayu@gmail.com
}

\begin{abstract}
Abstrak
Education must be carried out for it provides services for all people. Thus, Indonesian government conducts various policies. One of them is child-friendly city. This article has a purpose to explain the other side of education which facilitated Bukittinggi as one of childfriendly city in Indonesia. This research was carried out at PKBM Kasih Bundo, Bukittinggi. The research method is descriptive research. The research findings reflect some activities done by PKBM Kasih Bundo Bukittinggi in realizing Bukittinggi as child-friendly citiey, namely 1) organizing alternatives education, 2) services of child victim of human trafficking, 3) services of child victims of drugs and sex violence, and 4) services for children deviant behavior.
\end{abstract}

Keywords: Child-friendly city, Equality Education

\section{PENDAHULUAN}

Perwujudan dari peraturan Presiden mengenai Kota Layak Anak yang dilakukan secara terintegrasi antara pusat dan daerah dengan mencakup arah, sasaran, penyelenggaraan, pembinaan, dan pendanaan kebijakan. Sebagaimana yang tercantum pada deputi bidang tumbuh kembang anak. Kebijakan ini didukung pada pasal 22 Peraturan Presiden mengenai penyediaan sarana, prasarana, ketersediaan sumber daya manusia dalam penyelenggaraan perlindungan anak. Anak diberikan jaminan untuk memperoleh haknya dalam menyampaikan pendapat sesuai dengan usia dan tingkat kecerdasan yang salah satunya melalui pendidikan (Kementerian Hukum dan Ham, 2012).

Sebagai bentuk kerjasama semua pihak dalam mewujudkan kota layak anak terdapat peran masyarakat dalam penyelenggaraan perlindungan anak. Salah satu tanggung jawab masyarakat adalah melaksanakan dan menyediakan kegiatan dalam sebuah organisasi masyarakat dengan langsung berperan aktif serta melibatkan akademisi serta pemerhati anak. Selain itu anak juga memiliki perlindungan khusus dalam hal anak korban perdagangan, penyandang disabilitas, atau anak dengan prilaku menyimpang.

Sebagai tindak lanjut atas kejadian khusus yang disarankan pemerintah adalah penanganan secara cepat terhadap masalah anak, pendampingan psikososial, pemberian bantuan social, maupun pendampingan peradilan. Berdasarkan hal tersebut, upaya yang dapat dilakukan antara lain memberikan layanan dengan memberikan perlakuan secara manusiawi dengan memperhatikan kebutuhan anak sesuai dengan umurnya, menghindari penangkapan/ penahanan/ penjara kecuali hal tersebut alternative terakhir yang dapat dilakukan serta menyembunyikan identitas anak, dan pemberian pendidikan.

Jumlah Penduduk yang termasuk kategori Anak di Kota Bukittinggi tahun 2018 berjumlah 35.014 Jiwa atau 27,19\% dari Total Penduduk Kota Bukittinggi yang berjumlah 128.783 Jiwa. Upaya Pemerintah Kota Bukittinggi dalam mewujudkan 
Bukittinggi Kota Layak Anak sudah dirintis dan berhasil dengan memperoleh Predikat Kota Layak Anak Pratama Tahun 2017 dan Tahun 2018. Sedangkan Tahun 2019 Kota Bukittinggi telah berhasil meraih Kota Layak Anak Tingkat Madya dengan capaian layanan dan program meningkat menjadi 60 $\%$ Tahun 2019. Pemenuhan Hak Anak dalam berbagai aspek pemenuhan hak anak terus diupayakan pemerintah Kota Bukittinggi termasuk dengan ditetapkannya Peraturan Daerah Kota Bukittinggi Nomor 4 Tahun 2015 tentang Perlindungan Perempuan dan Anak.

Salah satu lembaga pendidikan yang mengimplementasikan program layak anak di Kota Bukittinggi adalah pendidikan nonformal. Salah satu penyelenggara berbasis masyarakat adalah Pusat Kegiatan Belajar masyarakat (PKBM) Kasih Bundo yang berada di Kota Bukittinggi. Berdiri semenjak tahun 2004 sampai saat ini, sudah banyak kasus yang berhubungan dengan pelayanan anak yang telah disolusikan pada PKBM Kasih Bundo. Anak-anak yang mengalami kejadian khusus telah dibina dan dilayani kebutuhannya serta diberikan haknya sehingga bisa kembali berbaur dalam masyarakat dengan pola layanan lembaga yang saling berkolaborasi antara dinas terkait.

Pusat Kegiatan Belajar Masyarakat Kasih Bundo terselenggara dibawah yayasan social yaitu YPPAC Kota Bukittinggi telah mengembangkan diagram pemutus rantai kemiskinan yang solusi utamanya adalah pendidikan (Bayu \& Meilisa, 2017). Wujud nyata kegiatan ini dilakukan melalui penyelenggaraan pendidikan nonformal berupa pendidikan kesetaraan. Secara berkesinambungan PKBM Kasih Bundo telah melakukan pendidikan dengan mengembangkan kemitraan bersama dinas pendidikan, dinas social, dinas kesehatan, perguruan tinggi, dan lembaga lainnya yang tujuan utamanya adalah berkoordinasi demi pelayanan terbaik terhadap anak. Kemitraan dengan perguruan tinggi dilakukan secara berkelanjutan dimulai dari peningkatan kompetensi pendidik dan tenaga kependidikan (Pasca, Bayu, Muhammadiyah, \& Barat, 2017), penyempurnaan modul pembelajaran (Putri et al., 2018), eksistensi diri peserta didik, dan penyediaan pembelajaran yang menyenangkan (Bayu \& Rahmayeni, 2018).

Penulis mencoba menjelaskan secara rinci program strategis yang telah dilakukan PKBM Kasih Bundo terkait pelayanan pendidikan layak anak dan kontribusinya terhadap pendidikan secara umum guna mencapat tujuan pendidikan nasional. Tujuan dari penulisan ini tidak lain untuk menjabarkan sisi lain pendidikan yang secara tidak langsung telah berperan besar memperbaiki masa depan anak yang pernah tidak diperhatikan atau melakukan tindakan "kreatif" yang berdampak buruk tidak hanya bagi diri sendiri, namun juga keluarga dan masyarakat.

\section{METODE}

Jenis penelitian yang dilakukan adalah penelitian deskriptif yang merupakan kegiatan yang menggambarkan informasi yang diperoleh secara apa adanya merujuk pada suatu standar yang ada sehingga memperoleh kesimpulan. Fakta, keadaan dan fenomena yang terjadi ketika penelitian sedang berlangsung disajikan apa adanya. Penelitian ini dilakukan secara Triangulasi yang dapat berupa Observasi, Dokumentasi, dan Wawancara (Laurent, 2012). Setiap kegiatan ini dijabarkan sebagai berikut: (1) Observasi. Observasi dilakukan untuk melihat kegiatan yang dilakukan sebagai wujud nyata aplikasi kota layak anak yang dilakukan PKBM Kasih Bundo. Penulis bertindak sebagai observer dalam pengumpulan data. (2) Dokumentasi. Dokumentasi dilakukan untuk mengetahui berbagai permasalahan anak yang pernah dihadapi PKBM Kasih Bundo beserta solusi yang pernah diberikan untuk mengatasinya. Dokumen yang diperlukan antara lain catatan kejadian, analisis awal peserta didik yang melanjutkan pendidikan pada jalur pendidikan kesetaraan, serta permasalahan 
dasar yang menjadi penyebab peserta didik memilih pendidikan kesetaraan. (3) Wawancara. Wawancara merupakan teknik pengumpulan data melalui proses Tanya jawab lisan yang berlangsung satu arah antara pewawancara dan subjek penelitian (Laurent, 2012). Penulis melakukan wawancara dengan peserta didik dan pendidik serta tenaga kependidikan berhubungan dengan penguatan terhadap pemberian layanan kepada anak.

Langkah yang dilakukan dalam pengumpulan data penelitian dilakukan melalui kunjungan secara berulang, wawancara mendalam kepada peserta didik sebagai penerima layanan serta wawancara dan perolehan dokumen dari pendidik dan tenaga pendidik yang ada di PKBM Kasih Bundo. Pengumpulan data dilanjutkan dengan analisis data (Pasca et al., 2017) sebagai berikut: (1) Reduksi data. Reduksi data dalam penelitian ini dilakukan dalam bentuk proses pemilihan, pemusatan perhatian, pemilihan, pengeditan dan penyederhanaan yang diperoleh dari catatan lapangan. (2) Penyajian data. Penyajian data dalam penelitian ini dilakukan dalam bentuk teks naratif berdasarkan hasil observasi, dokumentasi, dan wawancara yang kemudian direduksi selama penelitian berlangsung. (3) Verifikasi data. Verifikasi atau penarikan kesimpulan dalam penelitian ini dilakukan untuk meninjau ulang atau membuktikan kebenaran data yang telah diperoleh sebelumnya. Penarikan kesimpulan diambil berdasarkan fenomena yang terjadi serta impactnya terhadap peserta didik pada kondisi saat ini.

\section{HASIL PENELITIAN DAN PEMBAHASAN}

Pendidikan kesetaraan adalah pendidikan yang berlangsung di luar sistem persekolahan, namun kompetensi lulusannya setara dengan kompetensi lulusan pendidikan formal (persekolahan) setelah melalui ujian kesetaraan. Pendidikan kesetaraan memberikan andil yang cukup signifikan dalam menyumbangkan APK dan
APM pendidikan umum, baik Paket A setara SD/MI, Paket B setara SMP/MTs. Dan Paket $C$ setara SMA/MA. Paradigma pendidikan kesetaraan yang menganggap sasarannya adalah orang-orang kurang beruntung dan termarginalkan, perlu mengalami revolusi dan pencerahan. Sehingga dapat dikatakan bahwa pendidikan kesetaraan sudah menjadi pilihan.

Pemahaman tentang pembelajaran pada pendidikan kesetaraan yang pada dasarnya tidak hanya mempelajari tentang konsep, teori dan fakta, tetapi lebih mementingkan aplikasi dalam kehidupan sehari-hari, menuntut bagi para penyelenggara pendidikan untuk lebih bijaksana memilih pendidik yang kompeten di bidang pengetahuan dan pengalaman guna penerapan model-model dan strategi pembelajaran pendidikan kesetaraan. Sebagaimana yang telah diterapkan pada PKBM Kasih Bundo pendidik yang mengampu mata pelajaran tertentu harus linier dengan kompetensi yang dimiliki dan berstrata satu (UPI, 2012).

Pusat Kegiatan Belajar Masyarakat (PKBM) Kasih Bundo semenjak berdirinya telah menjadi solusi dalam menangani permasalahan anak. Berbagai permasalahan telah disolusikan dalam bentuk aplikatif yang membuat peserta didik dapat kembali percaya diri dengan kondisi masa lalu yang termarginalkan dan diremehkan masyarakat. Adapun beberapa permasalahan dan solusi yang telah dilakukan antara lain:

\section{Memberikan Layanan Pendidikan Alternative}

Berdasarkan data statistika (Kemdikbud, 2016) diketahui bahwa antara Angka Partisipasi Murni dan Angka Partisipasi Kasar terdapat perbedaan. Pada tingkat SD di Sumatera Barat diketahui terjadi selisih sekitar 6\%, pada tingkat SMP selisihnya sekitar $22 \%$, dan pada tingkat SMA memiliki selisih sekitar 18\%. Jumlah angka partisipasi dari SMP menuju SMA menurun $16 \%$. Hal ini berarti adanya peserta 
didik yang tidak melanjutkan pendidikan ke jenjang yang lebih tinggi.

Sebagai solusi untuk menampung peserta didik yang tidak dapat melanjutkan pendidikan formal, pendidikan kesetaraan merupakan alternative yang baik dan berkontribusi. Berdasarkan hasil yang diperoleh di lapangan diketahui bahwa PKBM Kasih Bundo menyediakan layanan pendidikan bagi anak yang tidak bisa memperoleh layanan pendidikan formal misalkan terkendala administrasi, ataupun peserta didik yang "kreatif" yang mengalami kegagalan disiplin pada pendidikan formal. Jumlah peserta didik yang telah dilayani pada PKBM Kasih Bundo dapat dilihat pada Tabel 1.

Tabel 1.

Jumlah Peserta Didik Pendidikan Kesetaraan Lima Tahun Terakhir

\begin{tabular}{|c|c|c|c|c|c|c|c|}
\hline \multirow[b]{2}{*}{ PROGRAM } & \multicolumn{6}{|c|}{$\begin{array}{c}\text { Peserta Didik Terdaftar Pendidikan Kesetaraan } 5 \\
\text { Tahun Terakhir } \\
\end{array}$} & \multirow[b]{2}{*}{ Jumlah } \\
\hline & $\begin{array}{c}2004 / 2005 \\
\text { S/D } \\
2013 / 2014\end{array}$ & $\begin{array}{l}2014 / \\
2015\end{array}$ & $\begin{array}{l}2015 / \\
2016\end{array}$ & $\begin{array}{l}2016 / \\
2017\end{array}$ & $2017 /$ & $\begin{array}{l}2018 / \\
2019\end{array}$ & \\
\hline $\begin{array}{r}\text { Paket A } \\
\text { Kls 4-6 }\end{array}$ & 370 & 60 & 77 & 95 & 91 & 57 & 715 \\
\hline $\begin{array}{l}\text { Paket B } \\
\text { Kls 7,8,9 }\end{array}$ & 1086 & 143 & 129 & 133 & 109 & 118 & 1602 \\
\hline $\begin{array}{c}\text { Paket C } \\
\text { Mahir } 1 \text { \& } 2\end{array}$ & 1124 & 92 & 116 & 108 & 79 & 69 & 1474 \\
\hline Jumlah & 2580 & 295 & 322 & 336 & 279 & 244 & 3797 \\
\hline Vokasional & 201 & - & 15 & 16 & 56 & - & 288 \\
\hline
\end{tabular}

Pendidikan harus memfasilitasi pelaksanaan karakter melalui keteladanan dilakukan peneladanan sebagai tindak lanjut piloting pendidikan karakter tahun 2010. Pengembangan lainnya dilakukan dengan Departemen agama melalui kegiatan tahsin setiap minggu. Kegiatan ini mendukung teori pendidikan behaviouristik yang merupakan perubahan tingkah laku sebagai akibat dari adanya interaksi antara stimulus dan respon (Santrock, n.d.).

Pendidikan inklusif adalah sistem penyelenggaraan pendidikan yang memberikan kesempatan kepada semua peserta didik yang memiliki kelainan dan memiliki potensi kecerdasan dan atau bakat istimewa untuk mengikuti pendidikan atau pembelajaran dalam satu lingkungan pendidikan secara bersama-sama dengan peserta didik pada umumnya. Dasar hukum dari pelaksanaan pendidikan ini adalah Peraturan Menteri Pendidikan Nasional RI Nomor 70 tahun 2009 tentang pendidikan 
inklusif yakni: Pemerintah daerah kabupaten/kota WAJIB menunjuk minimal satu sekolah perlevel pendidikan yang harus menyelenggarakan pendidikan inklusi di setiap kecamatan. Jumlah peserta didik yang mendapat pelayanan pendidikan inklusi di PKMB Kasih Bundo dapat dilihat pada Tabel 2.

Tabel 2. Jumlah Peserta Didik Yang Mendapat Pelayanan Pendidikan Inklusi Di PKMB Kasih Bundo Di Setiap Tingkat

\begin{tabular}{|c|c|c|c|c|}
\hline \multirow[b]{2}{*}{$\begin{array}{l}\text { Program } \\
\text { Pendidikan }\end{array}$} & \multicolumn{3}{|c|}{ Jenis Kedisabilitasan Peserta Didik } & \multirow[b]{2}{*}{ Total } \\
\hline & $\begin{array}{c}\text { Retradasi } \\
\text { Mental }\end{array}$ & $\begin{array}{c}\text { Kelainan } \\
\text { Fisisk }\end{array}$ & $\begin{array}{c}\text { Kelainan } \\
\text { Pengelihatan }\end{array}$ & \\
\hline Paket A (SD) & 18 & 2 & 1 & 21 \\
\hline Paket B (SMP) & 11 & 2 & 1 & 14 \\
\hline Paket C (SMA) & 0 & 5 & 1 & 6 \\
\hline
\end{tabular}

Peserta didik yang menyandang Retradasi Mental (kecerdasan dibawah ratarata) layanan pendidikan hanya diberikan sampai dengan tamat pendidikan Program Paket B karena rata-rata tingkat kecerdasannya 70-80 dan selanjutnya diarahkan dalam bentuk pendidikan keterampilan. Kegiatan pembelajaran dilakukan tanpa membedakan peserta didik, melibatkan dalam setiap kegiatan yang ada tanpa memandang kekurangan satu dan lainnya. Peserta didik ditanamkan untuk

mampu bertoleransi dan saling bekerja sama.

Memberikan Layanan Pendidikan Bagi Anak Korban Perdagangan Manusia.

Perdagangan orang (Trafficking) adalah tindakan merekrut, mengirim, memindahkan, menampung atau menerima orang untuk tujuan eksploitasi baik di dalam maupun di luar negeri dengan cara kekerasan ataupun tidak. Jumlah peserta didik di PKBM Kasih Bundo yang mengalami korban trafficking setiap tingkat dapat dilihat pada Tabel 3.

Tabel 3. Jumlah Peserta Didik di PKBM Kasih Bundo yang Mengalami Korban Trafficking di Setiap Tingkat

\begin{tabular}{|l|c|c|c|c|}
\hline \multirow{2}{*}{$\begin{array}{c}\text { Korban } \\
\text { Trafficking }\end{array}$} & \multicolumn{3}{|c|}{ Program Pendidikan } & \multirow{2}{*}{ Total } \\
\cline { 2 - 4 } & Paket A (SD) & Paket B (SMP) & Paket C (SMA) & \\
\hline Perempuan & 1 & 1 & - & 2 \\
\hline Laki-laki & - & - & - & - \\
\hline
\end{tabular}

Selain diberikan Pelayanan

Pendidikan, Layanan Konseling, pelayanan rehabilitasi sosial dan pemenuhan kebutuhan harian diberikan oleh YPPAC Kota Bukittinggi. Konseling diberikan untuk memberikan banyak layanan seperti pengembangan kehidupan pribadi, pengembangan hidup social, kemampuan belajar, dan pengembangan karir (Pusat Kurikulum Balitbang Depdiknas, 2011). Pengembangan kehidupan pribadi, yaitu bidang pelayanan yang membantu peserta didik dalam memahami, menilai, dan mengembangkan potensi dan kecakapan, bakat dan minat, serta kondisi sesuai dengan karakteristik kepribadian dan kebutuhan dirinya secara realistik.

Pengembangan kehidupan sosial, yaitu bidang pelayanan yang membantu peserta didik dalam memahami dan menilai serta mengembangkan kemampuan hubungan sosial yang sehat dan efektif dengan teman sebaya, anggota keluarga, dan warga lingkungan sosial yang lebih luas. Sedangkan pengembangan kemampuan belajar, yaitu bidang pelayanan yang membantu peserta didik mengembangkan kemampuan belajar dalam rangka mengikuti pendidikan sekolah/madrasah dan belajar secara mandiri. 
Bentuk kemitraan yang pernah dilakukan antara lain bekerjasama dengan perguruan tinggi negeri dan swasta di Kota Bukittinggi. Kegiatan ini melibatkan dosen dan mahasiswa yang memiliki kompetensi dibidang psikologi dan bimbingan konseling. Mitra melakukan kegiatan berkesinambungan setiap tahunnya.

Memberikan Layanan Pendidikan Untuk Anak Korban NAPZA Dan Korban Kekerasan Seks Serta Sodomi

Selama mendapat layanan pendidikan di PKBM Kasih Bundo, layanan rehabilitasi sosial bagi korban Napza khususnya dilakukan Rehabilitasi Napza bekerjasama dengan IPWL Agam Solid. Sementara untuk mereka yang menjadi korban seksual dan Sodomi dilayani konseling, psikologis dan pendampingan berbasis keluarga oleh P2TP2A (Pusat Pelayanan Terpadu Pemberdayaan Perempuan dan Anak) Kota Bukittinggi. Jumlah peserta didik di PKBM Kasih Bundo yang mengalami korban kekerasan dan NAPZA disetiap tingkat dapat di lihat di Tabel 4.

Tabel 4. Jumlah Peserta Didik Di PKBM Kasih Bundo Yang Mengalami Korban Kekerasan dan NAPZA di Setiap Tingkat

\begin{tabular}{|c|c|c|c|c|}
\hline \multirow{2}{*}{$\begin{array}{c}\text { Program } \\
\text { Pendidikan }\end{array}$} & Napza & $\begin{array}{c}\text { Kenis Korbanan } \\
\text { Seksual }\end{array}$ & Sodomi & Total \\
\cline { 2 - 5 } & 1 & 0 & 0 & 1 \\
\hline Paket A (SD) & 5 & 2 & 2 & 9 \\
\hline Paket B (SMP) & 6 & 1 & 0 & 7 \\
\hline Paket C (SMA) & &
\end{tabular}

Selain itu kegiatan juga melibatkan kepolisian dalam memberikan bantuan informasi kepada peserta didik berhubungan peraturan yang ada. Pihak kepolisian meluangkan waktu untuk berbagi dengan peserta didik pada lembaga PKBM Kasih Bundo yang berkesinambungan.

\section{Memberikan Layanan Bagi Anak Berprilaku Menyimpang}

Berdasarkan Kamus Besar Bahasa Indonesia perilaku menyimpang diartikan sebagai tingkah laku, perbuatan, atau tanggapan terhadap lingkungan yang seseorang dengan norma-norma dan hukum yang ada di dalam masyarakat. Peserta didik memiliki berbagai bentuk tingkah laku yang memerlukan pembimbingan dari orang dewasa yang akan menuntun pada bentuk tingkah laku yang baik. Jumlah peserta didik di PKBM Kasih Bundo yang memiliki perilaku menyimpang (pekerja seks, lesbian, gay) di setiap tingkat dapat dilihat pada Tabel 5.

Tabel 5. Jumlah Peserta Didik Di PKBM Kasih Bundo Yang Mengalami Korban Trafficking Setiap Tingkat.

\begin{tabular}{|l|c|c|c|c|}
\hline \multirow{2}{*}{$\begin{array}{c}\text { Program } \\
\text { Pendidikan }\end{array}$} & \multicolumn{3}{|c|}{ Jenis Prilaku Menyimpang } & \multirow{2}{*}{ Total } \\
\cline { 2 - 5 } & Pekerja Seks & Lesbian & Gay & 2 \\
\hline Paket A (SD) & 1 & 1 & 0 & 8 \\
\hline Paket B (SMP) & 6 & 1 & 1 & 3 \\
\hline Paket C (SMA) & 2 & 0 & 1 & \\
\hline
\end{tabular}


Bagi pekerja seks yang menjadi peserta didik PKBM Kasih Bundo merupakan hasil Razia Satpol PP Kota Bukittinggi dan telah mendapatkan Rehabilitasi Sosial di Panti Sosial Karya Wanita (PSKW) Andam Dewi, Kabupaten Solok. Sementara yang Lesbian selama pmengikuti Pendidikan juga diberikan Program Konseling, Layanan Psikolog bersama P2TP2A Kota Bukittinggi.

Berdasarkan hal tersebut, diketahui bahwa peserta didik dapat disolusikan karena adanya kemitraan dengan berbagai pihak dengan memberikan kepercayaan penuh pada lembaga tanpa secara kooperatif. Kegitan ini perlu dikembangkan oleh lembaga lainnya untuk dapat mensolusikan berbagai permasalahan pendidikan.

\section{KESIMPULAN DAN REKOMENDASI}

Sebagai lembaga yang menjalankan pendidikan yang mensolusikan kebutuhan peserta didik, PKBM Kasih Bundo telah mendukung kegiatan pemerintah untuk mewujudkan kota layak anak di Bukittinggi. Hal ini telah ditunjukkan melalui kegiatan untuk menanggulangi kejadian khusus tentang anak. Adapun kejadian khusus yang telah pernah disolusikan antara lain diwujudkan dalam pendidikan alternative dan pendidikan inklusi, layanan pendidikan bagi anak korban perdagangan manusia, layanan pendidikan korban NAPZA dan kekerasan seks, serta layanan bagi anak berprilaku menyimpang. Semua peserta didik sudah dapat mengikuti perkembangan dalam kehidupannya dengan baik untuk mengaktualisasikan diri secara pribadi, social, dan pembelajaran.

\section{DAFTAR KEPUSTAKAAN}

Bayu, E. P. S., \& Meilisa, M. 2017. Assistingthe Government in the Implementation Non-Formal Education: A Case Study of the Indonesian Kasih Bundo Institute for the Care and Development of the Disable Children. COUNSEDU: The International Journal of Counseling and Education.Vol. 2. No. 3.
Bayu, E. P. S., \& Rahmayeni, R. 2018. Metode Games Is Magic Pada Pembelajaran Matematika Program Paket A PKBM Kasih Bundo. Unes Journal of Education Scienties. Vol. 2. No. 1.

Kementerian Hukum dan Ham. 2012. Undang-Undang Perlindungan Anak. Undang Undang, 1.

Kementerian Pendidikan dan Kebudayaan. 2016. Apk/Apm 2015/2016. Retrieved from publikasi.data.kemdikbud.go.id

Laurent, N. 2012. Basic of Sosial Research. In Pearson Education Limited. Vol. 66.

Pasca, E., Bayu, S., Muhammadiyah, U., \& Barat, S. 2017. Workshop Kurikulum Pendidikan Non Formal Dengan Menelaah Standar Isi Dan Standar Proses. Jurnal Curricula. Vol. 2. No. 1.

Pusat Kurikulum Balitbang Depdiknas. 2011. Model Pengembangan Diri. Jakarta Pusat: Pusat Kurikulum dan balitbang Depdiknas.

Putri, N. A., Kurnia, L., Pasca, E., Bayu, S., 2018. Pengembangan Lembar Kerja Siswa ( LKS ) dengan Pendekatan Kontekstual pada Pendidikan Kesetaraan Paket B Setara Kelas VII SMP / MTs di Kecamatan Mandiangin Koto Selayan Kota Bukittinggi. Proceeding IAIN Batusangkar. Vol. 3. No. 2.

Santrock, J. W. (n.d.). Educational Psychology; SIXTH EDITION.

Usup. 2012. Efektivitas Program Pembelajaran TerhadapKompetensi Lulusan Pendidikan Kesetaraan Paket CUniversitas Pendidikan Indonesia. Tesis UPI. Tidak diterbitkan. Akses di repository.upi.ed. 
Perwujudan Indonesia Layak Anak (Studi Kasus PKBM Kasih Bundo Kota Bukittinggi sebagai Penyelenggara Pendidikan Kesetaraan) 